\title{
Telemedicine: contributions, difficulties and key factors for implementation in the prison setting
}

\author{
Mateo $\mathrm{M}^{1}$, Álvarez R $\mathrm{R}^{1}$, Cobo $\mathrm{C}^{2}$, Pallas JR ${ }^{2}$, López $\mathrm{AM}^{2}$, Gaite L \\ ${ }^{1}$ Health Centre of "José Hierro" Social Integration Unit. Santander. \\ ${ }^{2}$ El Dueso Prison Health Centre. Santoña.. Cantabria. \\ ${ }^{3}$ Evaluation Unit. Psychiatry Service. Marqués de Valdecilla University Hospital. CIBERSAM
}

\begin{abstract}
Information and communication technologies are transforming the way we understand health, via a hyper-connected world in which patients, professionals and society take on new challenges and roles. This change is creating an ecosystem called connected health, in which telemedicine acquires special importance when distance (not only geographical), is a critical factor. It can respond to financial, social or safety needs or questions of dignity, as is the case with prisoners when they are transferred handcuffed and under custody to hospitals. Bringing health services closer to patients who cannot autonomously travel contributes towards humanising healthcare.

Tele-consultations, long-distance encounters between patients and health professionals, reduce the direct and social costs inherent to habitual clinical practice and are very highly valued by patients in prison. Despite its potential benefits in the prison setting, the implementation of telemedicine in Spain continues to be scarce and irregular, which, amongst other things, is due to a lack of awareness of this healthcare practice, the severe shortage of resources currently endemic to the prison health service system and the lack of interoperability solutions for clinical information between the healthcare administration and the prison health services, which unfortunately continue to depend on an organisation outside the healthcare ambit (the Ministry of Home Affairs), despite the legal provisions requiring them to be fully integrated into regional health services.

The SARA (Administration Applications and Networks Systems) Network and the Reúnete ${ }^{\odot}$ Service offer solid, secure, free technology is available to all prisons, to set in motion telemedicine programs at a nationwide level.
\end{abstract}

Keywords: prisons, telemedicine, electronic health records, remote consultation, videoconferencing.

Text received: 07/04/2019

Text accepted: 15/04/2019

\section{TELEMEDICINE (TMD): WHAT ARE WE TALKING ABOUT?}

TMD is the long-distance exchange of clinical information, in which information and communication technologies (ICT) are used. Although there are many definitions ${ }^{1}$, we selected the one used by the American Telemedicine Association (ATA), which describes it as "the use of medical information exchanged from one site to another via electronic communications to improve patients' health status"2. Telehealth, which is a concept very closely linked to TMD, is a broader term that covers all forms of longdistance health service provision, including non-clinical services ${ }^{2}$, such as tele-training, web portals for patients, or virtual meetings of health teams. There are new terms to define a hyper-connected world that is changing the way we understand health. Apps for health and wellbeing for mobile devices, between 400,000 and 500,000 in $2018^{3}$, body and local sensors, the new era of the Internet of Things, in which any everyday object is computerised and connected ${ }^{4}$, cloud computing services, or the potential of big data to improve the quality of healthcare ${ }^{5}$, are examples of an ecosystem in which the definition of telehealth falls short of what is actually happening, and where new expressions are being coined, such as health 2.0, digital health or connected health are being coined, which, as the Spanish Society of Healthcare Information Technology (SEIS) declares", would be "the 


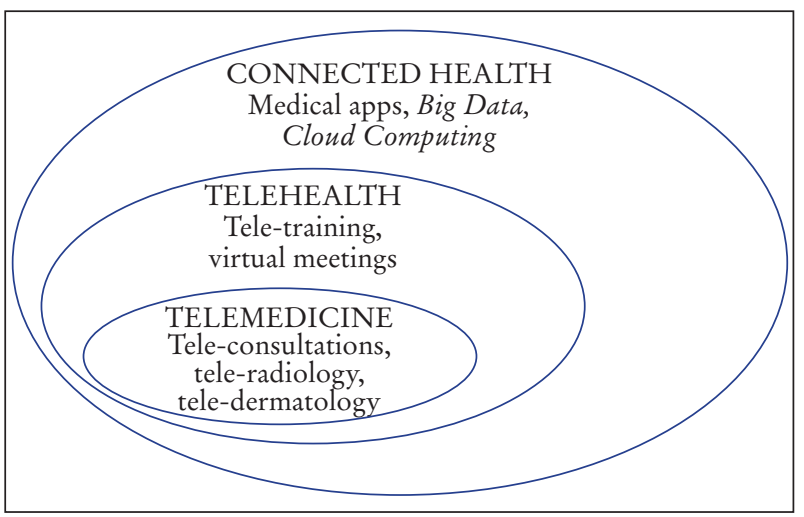

Figure 1. Telemedicine in the connected health ecosystem.

final evolutionary link arising from the introduction of information and communication technologies into healthcare" (Figure 1).

TMD can be regarded as a clinical branch of telehealth that is given over to patient care, divided into synchronous and asynchronous, depending on whether the remote clinical services are provided in real time or are time-delayed. Tele-consultations are clinical meetings between a health professional at one end and a patient at the other, which use real time videoconference systems (synchronous). An example of asynchronous TMD is tele-radiology. A radiological image is taken at the patient's end, which is transmitted to the hospital's digital archiving system (PACS, Picture Archiving and Communication System) for which the $\operatorname{DICOM}^{7}$ (Digital Imaging and Communication in Medicine) standard is used. The image is remotely interpreted and in "delayed time" by the radiology specialist, and report is created in the electronic clinical history.

High quality TMD should be understood as a new way of relating to patients, with the same efficacy and legal validity as usual clinical practice (UCP), but using different channels for this purpose.

\section{CONTRIBUTIONS OF TELEMEDICINE: WHEN DISTANCE (NOT ONLY GEOGRAPHIC) IS A PROBLEM}

Since its origins in the 60s, TMD has been conceived of as a solution for providing health services when there were geographical barriers that acted as a barrier to face-to-face clinical care. Along these lines, the World Health Organisation states that TMD acquires considerable importance when distance is a critical factor ${ }^{8}$.

The tele-consultation and tele-training system created in 1964 between the Institute of Psychiatry of the University of Nebraska (Omaha) and Norfolk Psychiatric Hospital (Virginia), separated by 112 miles, was the first solid experience in the use of TMD linked to problems of distance ${ }^{9}$, which was followed by other projects such as those designed by NASA in 1967 for tele-monitoring the vital signs of the astronauts who formed part of the Apollo space missions, or the TMD project "STARPAHC" created by the Indian Health Service (IHS), NASA and the Papago tribe in Arizona 9 . In the 70 s and 80 s the USA was already designing a federal TMD agency and created a national network based on videoconferencing, placing the work stations in rural areas. This practice extended in 1970 to Switzerland, Great Britain and other countries ${ }^{10}$, and the number of specialisations that teleconsultation-based TMD was applied to progressively increased (tele-psychiatry, tele-electrocardiography, mentoring in anaesthesiology, neonatology or intensive care, etc.) $)^{9}$. In this period (1970-1980), TMD was also extended to prisons, with examples such as the tele-consultations between Dade county prison, the University of Miami and Jackson Memorial Hospital'.

TMD has been developing worldwide, patchily but with a constant upward trend, and in the meantime the strict criterion of geographical distance has been diluted to take another wider approach that focuses on difficulties of access to health services, which may be understood as "non-geographical distance". Persons with problems of mobility, institutionalised patients, persons with severe mental disorders whose affective or negative symptomatology makes it difficult for them to leave their homes or area of residence, situations of social exclusion, lack of human or financial resources to assist them in travelling, are just some examples of non-geographical distance to health services. As we shall discuss below, incarcerated persons have all these difficulties with the added hardships associated with the journeys and transfers required for them to access health centres in the civil network when they need specialised care.

The criterion of non-geographical distance continues to extend and encompass other issues and is taken into consideration in models of economic evaluation, where the impact of indirect costs on access to healthcare from a social perspective is calculated ${ }^{11}$, or rather, by calculating the economic repercussions it has for patients and for society, when people no longer produce or contribute because they have to interrupt their paid job to go to a clinical examination, and comparing this state of affairs with healthcare via tele-consultation.

The final link in "non-geographical distance" includes the patient's preferences, which are increa- 
singly important for implementing telehealth services. A study carried out in the USA ${ }^{12}$ in 2017 , based on a survey taken with a representative sample of the adult population (4,345 Americans), concluded that the majority prefer to use TMD with their own doctor, with whom they have an established relationship, and highlights convenience as the most important factor in their decision. This emerging model of patient relations via TMD, based on their own preferences, is also now offered in Spain as part of the private healthcare system $^{13}$, highlighting features such as patient convenience and the attractive prices of the services.

\section{TMD IN THE PRISON SETTING: REASONS AND DIFFICULTIES IN STARTING}

\section{Reasons}

When TMD is compared to UCP in the prison setting, it can be seen that it reduces patients' nongeographical distances to health services for a number of reasons. In UCP, the journeys and transfers have negative implications for patients:

- They are complex and expensive: they require search and identification processes, security checks, police custody and special vehicles.

- They take up a lot of time: collective vehicles are used that wait for all the consultations or even court cases to end, leading to wasted working, training or rehabilitation hours for the patients.

- They affect the patient's dignity, as they are seen in public spaces under custody and wearing handcuffs. The stay in prison limits rights that should go not further than strictly necessary to comply with the purposes of internment.

Tele-consultations minimise costs when they are compared to those of UCP. In a study published by our group in Cantabria ${ }^{14}$, a cost minimisation analysis was conducted on a TMD program in managing infection from the hepatitis $\mathrm{C}$ virus (HCV) in a cohort of 77 patients incarcerated in the El Dueso Prison, between January and December 2016, comparing it with what would have taken place in the UCP. The study included direct costs: medical (consultations with specialists, analyses, ultrasound scans, FibroScan, gastroscopy), non-medical (transfers to the hospital), and the indirect costs from a social perspective, which come from the working hours lost by inmates in their work in the prison (while they did not form part of the study, the social perspective can also include hours lost in occupational, educational or treatment activities). Figure 2 shows that the average cost per patient of TMD was $1,196 €$ compared to $1,774 €$ in UCP,

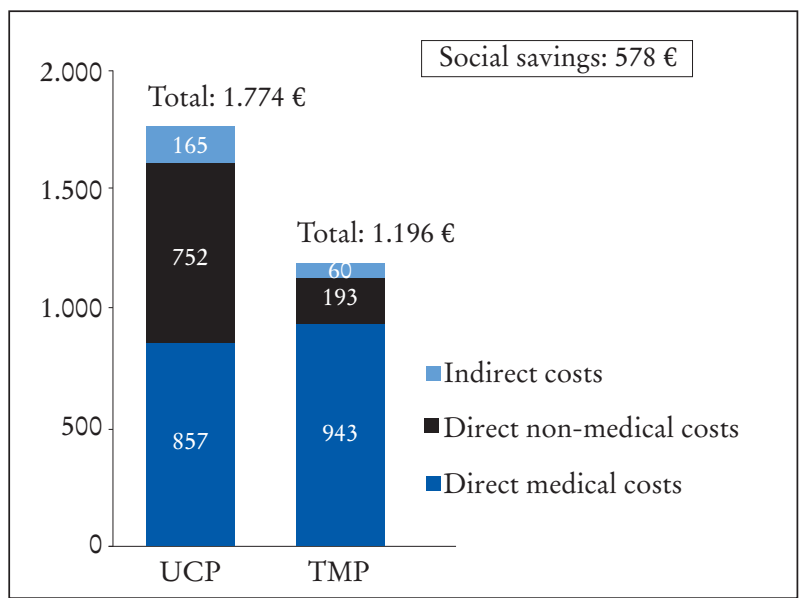

Figure 2. Costs per patient in euros $(€)$ of management of hepatitis $\mathrm{C}$ virus $(\mathrm{HCV})$ as part of the strategy of a telemedicine program (TMP) and in usual clinical practice (UCP). January-December 2016, at Dueso Prison.

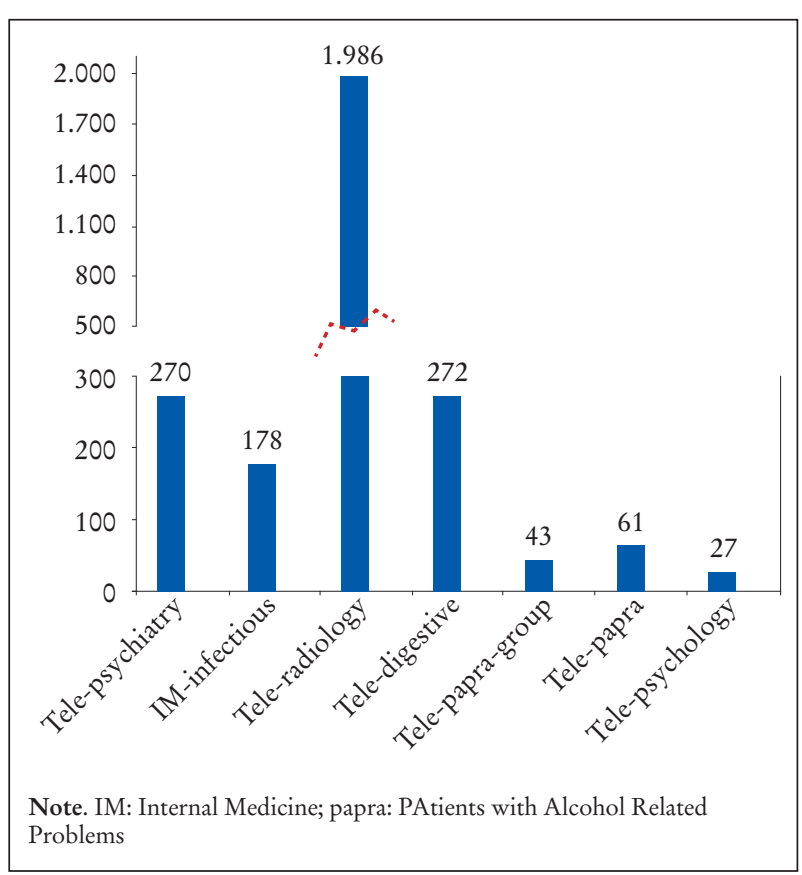

Figure 3. Number of tele-consultations and tele-radiology sessions between October 2015 and March 2018 carried out at Dueso Prison.

although direct medical costs are higher when using TMD, as it consumes resources at the patient's end because a prison health professional participates in the process.

TMD is very positively accepted by patients in prison. Dueso Prison has considerable experiences in the use of TMD. Between October 2015 and March 2018, a total of 851 tele-consultations and 1986 radiological tele-examinations were carried out (Figure 3), in which patients' levels of satisfaction with the ser- 
Table 1. Satisfaction survey offered to each patient after the teleconsultation

\begin{tabular}{|c|c|}
\hline $\mathrm{P} 1$ & I could clearly see the specialist on the screen \\
\hline P2 & $\begin{array}{l}\text { I could clearly hear the specialist through the } \\
\text { loudspeakers }\end{array}$ \\
\hline P3 & $\begin{array}{l}\text { The specialist could hear me without any } \\
\text { problems }\end{array}$ \\
\hline P4 & $\begin{array}{l}\text { I felt comfortable talking to the specialist via the } \\
\text { screen }\end{array}$ \\
\hline P5 & $\begin{array}{l}\text { I was no more nervous than usual when the } \\
\text { consultation started }\end{array}$ \\
\hline P6 & I was relaxed during the consultation \\
\hline P7 & I could explain what I wanted to the specialist \\
\hline P8 & I understood the specialist's instructions \\
\hline P9 & $\begin{array}{l}\text { I am happy with the punctuality of the } \\
\text { consultation }\end{array}$ \\
\hline P10 & $\begin{array}{l}\text { My privacy and confidentiality was respected in } \\
\text { the consultation }\end{array}$ \\
\hline P11 & I am generally satisfied with the service received \\
\hline
\end{tabular}

vice received was evaluated. At the end of each teleconsultation, the patient completed a Likert ${ }^{15}$ type 5 point satisfaction survey (Table 1), designed in line with the criteria of centres with expertise in $\mathrm{TMD}^{16-18}$. The survey included questions on technical matters (P1-P3), convenience (P4-P6), understanding (P7$\mathrm{P} 8)$, organisation (P9), confidentiality (P10) and overall satisfaction (P11).

Figure 4 and Table 2 shows an analysis of the results of the first 200 satisfaction surveys corresponding to the consultations for tele-psychiatry and tele-digestion, carried out between January 2016 and December 2017. The answers to each question had a minimum score of 1 and a maximum of 5 , according to the level of satisfaction. The average score for each question was over 4 points, which indicates a high level of perceived satisfaction.

Telehealth in the prison setting provides additional advantages, reducing the non-geographical distance between health professionals:

- It enables tele-training to be given, this avoiding the isolation of healthcare teams working in prisons.

- It offers innovative solutions for virtual multidisciplinary meetings. In Cantabria, coordinated care of severe cases of mental disorders has been conducted since 2018 via virtual sessions with a case analysis team consisting of professionals working in mental health, primary healthcare, addictive behaviour units, managers of the regional health service, the chronic disease service, psycho-social rehabilitation centres, social services, foster care services, prison healthcare and legal medicine institute. This enables there to be monthly contact between over 32 professionals without their having to leave their places of work. Every meeting lasts 60 minutes at most.

\section{Difficulties}

Although there are pertinent reasons that make the deployment of TMD in prisons advisable (this refers to the package consisting of access to the regional electronic clinical history, tele-consultation service and dispatch of medical images), its use continues to be very limited and geographical distribution is scattered. The report by the General Secretary of Prisons (SGIP) of 2017 states that only 1,228 tele-consultations were carried out, compared to 47,295 consultations with transfers outside the prison (UCP) ${ }^{19}$. The number of prisons that access the regional clinical history is very limited, in 2016, 18 out of 68 prisons had some kind of access to electronic clinical history services $(\mathrm{ECH})$, including the Basque Country (own data). The Ombudsman's report of $2017^{20}$ reiterated that there are still difficulties in extending healthcare services to incarcerated persons via TMD, and that it is necessary to make greater efforts to make this clinical practice more widespread.

The lack of development of TMD in prisons is due to a number of factors:

- Lack of information: there are no guidelines from the General Secretary of Prisons on developing TMD programs at regional levels. We would recommend a TMD framework program for prisons containing the technical. legal and operational aspects that prisons need to know in order to implement TMD programs in conjunction with regional administrations.

- Security and cost: if TMD business solutions are chosen with access to the Internet or special hardware requirements, security restrictions in inmate transfer areas may arise, alongside the public costs that would be generated.

- Consumption of resources at the patient's end: tele-consultations require medical staff at the prison who are responsible for organising the meeting between the patient and the specialist, and who should be available for dealing with any technical or medical contingencies during the session. This need for availability may be affected by the dire shortage of resources in the prison health services, as indicated by the Ombudsman in his report of $2017^{20}$. 


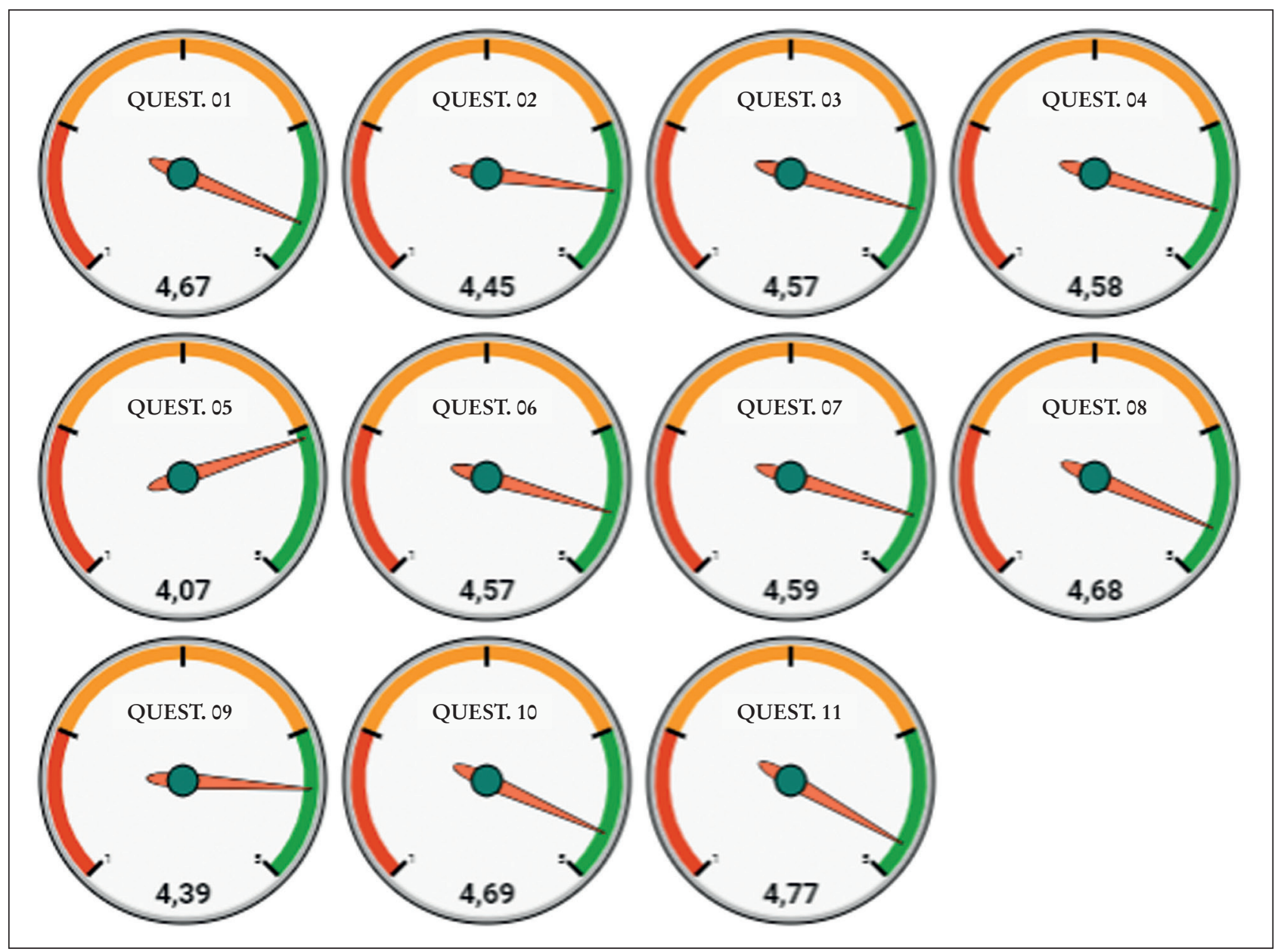

Figure 4. Results of the satisfaction survey for psychiatric and digestive tele-consultations at Dueso prison in 2016-2017.

Table 2. Results of the satisfaction survey on tele-consultations for psychiatry and digestive in Dueso Prison 2016-2017

\begin{tabular}{lccccccccccc} 
& Quest. & Quest. & Quest. & Quest. & Quest. & Quest. & Quest. & Quest. & Quest. & Quest. & Quest. \\
02 & 03 & 04 & 05 & 06 & 07 & 08 & 09 & 10 & 11 \\
Mean score & 4,6 & 4,4 & 4,5 & 4,5 & 4,0 & 4,5 & 4,5 & 4,6 & 4,3 & 4,6 & 4,7 \\
\hline $\begin{array}{l}\text { Confidence } \\
\text { Interval } \\
\text { (CI 95\%) }\end{array}$ & $\begin{array}{c}4,5 \text { to } \\
4,7\end{array}$ & $\begin{array}{c}4,3 \text { to } \\
4,5\end{array}$ & $\begin{array}{c}4,4 \text { to } \\
4,6\end{array}$ & $\begin{array}{c}4,4 \text { to } \\
4,6\end{array}$ & $\begin{array}{c}4,0 \text { to } \\
5,0\end{array}$ & $\begin{array}{c}4,4 \text { to } \\
4,6\end{array}$ & $\begin{array}{c}4,4 \text { to } \\
4,6\end{array}$ & $\begin{array}{c}4,5 \text { to } \\
4,7\end{array}$ & $\begin{array}{c}4,2 \text { to } \\
4,5\end{array}$ & $\begin{array}{c}4,5 \text { to } \\
4,7\end{array}$ & $\begin{array}{c}4,6 \text { to } \\
4,8\end{array}$ \\
\hline
\end{tabular}

- Need to maintain two electronic clinical history systems, belonging to the prison and regional health services. The lack of solutions for interoperability between both systems implies that the prison healthcare centre will have to manually update the medical information in one or two addresses (depending on if it has writing per- mits in the regional ECH) generated by the teleconsultations in one or two addresses (progress reports, diagnoses and prescriptions.

It should be pointed out that it is not desirable to have a TMD strategy that is geared towards making up for the shortages of primary healthcare professionals in prisons. Prison health centres are and should 
continue to be the access node for incarcerated persons to primary healthcare services, where a faceto-face meeting with health teams is a key factor in contributing towards reducing the isolation caused by imprisonment. The same feelings were expressed by Michelle Andrews, columnist of the Kaiser Health News $(\mathrm{KHN})^{21}$, in an article that stressed the capacity of TMD in American prisons, with wide ranging implementation ${ }^{22}$, as a complement that opens doors for prisoners to specialists, as long as there are prior face-to-face consultations in the prison.

\section{TELEMEDICINE IN PRISON: KEY ASPECTS OF THE PROJECT}

Several key aspects should be taken into consideration when designing a TMD project in a prison setting:

\section{Legal force of tele-consultations}

Spain has no specific legislation on the use of teleconsultations. Therefore the same requirements as in usual clinical practice should be guaranteed to ensure that the healthcare is legally valid:

- Confidentiality: Given that the audiovisual or textual traffic from tele-consultations is health data, it should be protected under the provisions of current data protection legislation.

- Autonomy: respect for the patient's autonomy in decision making should be ensured when receiving health services via the TMD. Informed consent in writing is a good practice in this regard.

- Records: the medical activities in the tele-consultations should be recorded in the clinical history under the same conditions as in UCP.

\section{Scope of the regional ECH services with regard to the prison}

This is a milestone in the project design, as it permits the exchange of healthcare information generated in the tele-consultations and other telehealth procedures, thereby ensuring continuity of treatment.

\section{Legal grounds for the right of access to regional} ECHs by prison health services

The Spanish Data Protection Agency (AEPD) answers this question in report $18 / 2006^{23}$ :

- The AEPD considers that the inmate's consent is not required to permit prison medical staff to consult any existing data in the centralised clinical history file in a regional health system, not even for processing by prison medical staff and inclusion in the centralised clinical history file, although the inclusion of any data that might make public the fact that the treatment was provided by a prison health service should be avoided.

- The report also states that "The prison health services should be regarded as medical establishments incorporated into the National Health System, for the purposes established under Law 16/2003, of 28 May, on Cohesion and Quality of the National Health System". This point is essential in justifying access by prison health professionals to regional medical information, under the same conditions as any other health centre. The contents of this report served as a legal argument to permit prisons in Cantabria to access all the ECHs in 2012.

\section{Selecting the technology: SARA Network (Administration Applications and Networks Systems)}

The SARA Network (Administration Applications and Networks Systems) enables public administrations to reach out to each other and share all the services they consider to be necessary, including regional ECH systems. It is an ideal solution for developing TMD in the prison setting for the following reasons:

- It offers communications infrastructures, state of the art technology, 24 × 7 × 365 support, encrypted traffic, and is maintained with public funds while its use does not entail an increase in expenditure.

- It permits secure communications in the Corporate Network of the Autonomy, via a connection area (CA) to the corporate networks of other public administrations that are connected (Figure 5).

- It is compatible with the security restrictions in inmates' transit zones, since it requires no access to Internet to reach the services.

- It is available to all prisons from any authorised device.

\section{Tele-consultations program in Cantabria}

Given the problem-solving capacity of tele-consultation, its demand in prisons and local availability, whatever specialities considered to be appropriate can be selected. the following services are available at the Dueso Prison:

- Tele-psychiatry: a speciality with considerable demand, since the prison systems receive a high 


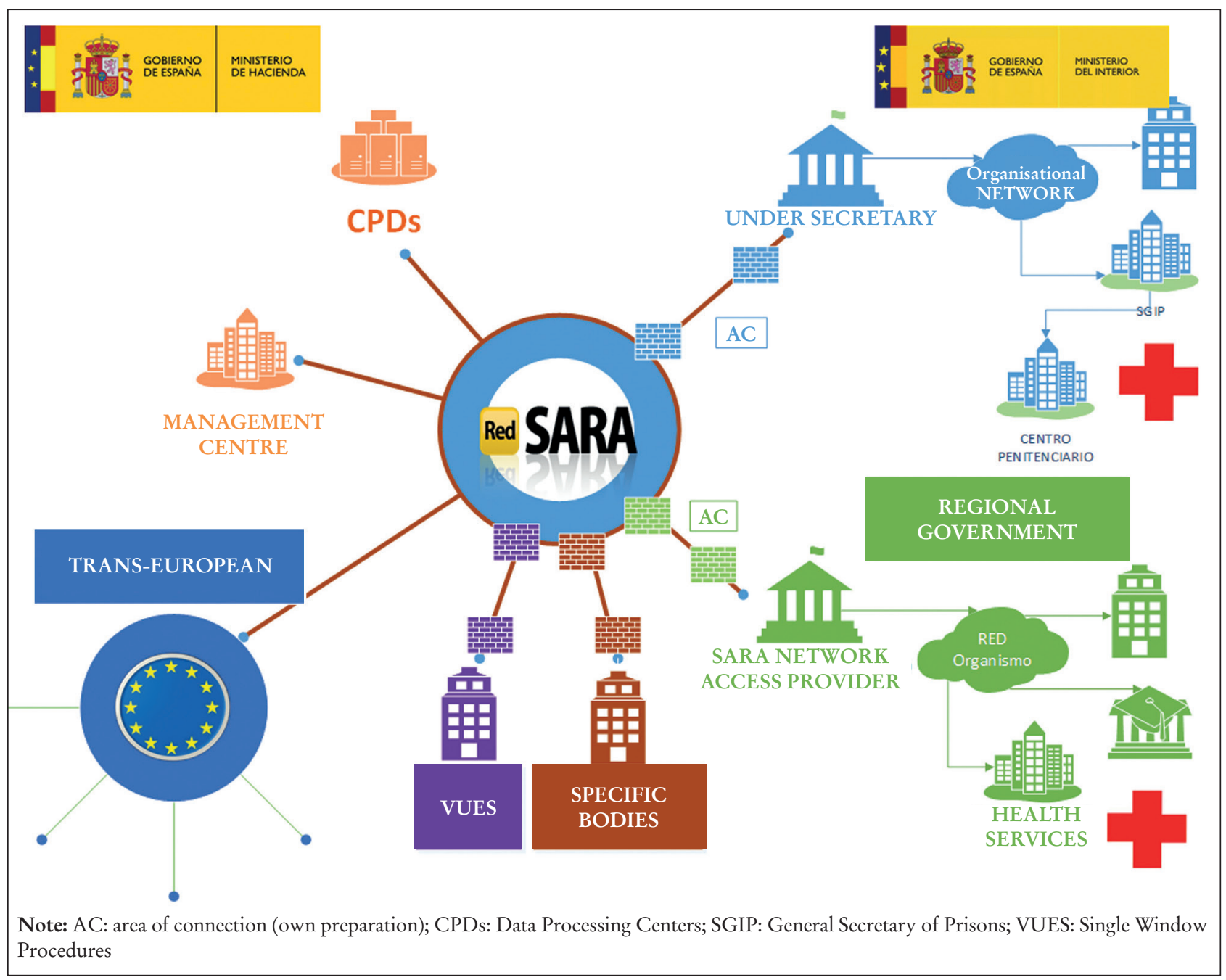

Figure 5. Diagram of connections of the SARA Network for the Ministry of Home Affairs.

proportion of persons diagnosed with mental disorders, along with others suffering from substance consumption disorders. According to the report on the prevalence of mental disorders in Spanish prisons (PRECA), the prevalence of psychiatric illnesses in the Spanish prison population is five times higher than that of the general public ${ }^{24}$. Mental health is seen as the ideal scenario for applying TMD, as diagnosis and treatment are mostly carried out via audiovisual communication. Alongside tele-psychiatry, other services are offered such as tele-psychology and TMD for treating addictive behaviours (in individual and tele-group modalities) by hospital in the Cantabria public network.

- Tele-infectious diseases and tele-digestion in the context of therapeutic management of hepatitis C, infection by the human immunodeficiency virus
(HIV) and HIV-HCV co-infection in prison, due to their high prevalence in comparison to the general public. A recent publication by our group in the American Journal of Gastroenterology, presents the result of a strategy of micro-elimination of hepatitis C in Dueso Prison via TMD, which has drastically reduced the number of transfers to hospital, and which also obtained a high level of perceived satisfaction from patients ${ }^{25}$.

\section{Reúnete ${ }^{\circledR}$ Service of the SARA Network}

The technology recommended for tele-consultations in the prison setting is Reúnete $\odot$, the Common Virtual Meetings Service of the SARA Network. It is a collaborative tool that offers high quality web videoconferencing that is encrypted and provides $24 \times 365$ backup, and is free of charge for public administrations. It permits up to ten simultaneous connections, 
does not require Internet, and can be deployed in any IT device available in the consultations area.

\section{Provision of other specialties recommended for prison via TMD}

- Tele-radiology: high demand in prisons meant that 31,496 radiological studies were carried out in $2017,73.6 \%$ of them inside prisons ${ }^{19}$. a conventional $\mathrm{X}$ ray unit is required that can send digital images in standard DICOM (Digital Imaging and Communications in Medicine), as well as professionals trained to carry out examinations. The images sent from the prison to the public health centre PACS, and the extent of the RIS, (Radiology Information System) se are carried out via the SARA Network.

- Tele-dermatology for diagnostic and monitoring purposes: photographic images are taken in the prison, in line with clinical guidelines to ensure quality $^{26}$ agreed with the dermatology service, and are sent via medical messenger service HL7 (Health Level Seven) if available ${ }^{27}$, or directly to the hospital PACS, using the SARA Network in both cases.

\section{Operational and organisational aspects}

\section{Informed Consent}

A written informed consent form that guarantees patient autonomy for receiving treatment via TMD is recommended.

An informed consent form is available in Cantabria $^{28}$, based on the guidelines of the American TMD Association ${ }^{2}$, which contains the following information:

- The sort of tele-consultation and what it involves.

- The risks and benefits, efficacy and potential risks (caused by security failures, very rare).

- The security measures for health data protection and the patient's privacy when the documentation and information is shared between two sites.

- The video-consultations are not recorded. Separate written approval is required along with the patient's consent prior to any recording.

- There are policies and procedures established in the event or technical failures or clinical emergencies.

- The patient is informed that he/she has the option of rejecting treatment via TMD and, if so, is guaranteed the option of receiving face-to-face treatment.

\section{TMD procedures}

Documented procedures on TMD should be drawn up that contain at least the following specifications:
- Technical guide for running a video session: how to connect, features of the devices, where to place the camera, screen and loudspeakers.

- Environmental aspects of the room at the professional's and patient's end: furniture, lighting, comfort, sound insulation, recommended colours for walls.

- Coordination between patient's end and that of the health professional: times of video-consultations, operational checks, alternative telephone channel.

- Recording procedure of the tele-consultation clinical progression, diagnosis and treatment plan on the regional $\mathrm{ECH}$.

- A technical and clinical contingency plan (including patient unavailability) for both ends.

Our group has a documented system containing a general procedure for tele-consultation ${ }^{29}$ and a series of specific procedures for each specialty available via TMD. The main guidelines of the American TMD Association are recommended for preparing such procedures ${ }^{30,31}$.

\section{Legislative framework for implementing TMD programs in the prison setting. Agreements: yes or no?}

A extensive TMD program has been deployed in Cantabria that includes full reading and writing access to the regional ECH systems, tele-radiology, teledermatology and multiple tele-consultations, without the need for a collaboration agreement between the Ministry of Home Affairs and the Regional Government. This was made possible by considering, from the outset (and acting accordingly), that the prison health services are medical establishments included in the National Health System, as indicated by the Spanish Data Protection Agency in its report 18/2006 23.

Creating a collaboration agreement that regulates TMD projects is reasonable inasmuch as when there continue to be breaches by the public administrations of the Law of Cohesion and Quality of the National Health System, which imposes the obligation to transfer prison health services to autonomous communities. Given the current difficulties in entering into agreements on specialised healthcare in prison, legal analyses should be carried out to find alternative solutions, such as coordination protocols, which express the intention of administrations to act with a common objective, without the need to execute specific and enforceable legal commitments. 


\section{KEY POINTS}

1. Deployment of TMD in prisons is scarce and irregular, although non-geographical issues work as a powerful argument in favour of its use.

2. TMD contributes towards humanising the healthcare of incarcerated persons, by avoiding transfers and the appearance of patients in public places, and by facilitating faster and more efficient access to specialist treatment. It also greatly reduces direct non-medical and social costs.

3. Treatment via tele-consultations produces a high level or perceived satisfaction by patients incarcerated in prison.

4. Primary health care should continue to be provided via usual clinical practice in prison health centres. But TMD is not designed to deal with any existing shortages of health professionals.

5. A TMD program consumes more resources at the patient's end than usual clinical practice, which has to be quantified and guaranteed before commencing a project of this type.

6. Access to the regional electronic clinical history by a prison health centre is a key milestone for TMD programs.

7. The SARA Network and the Reúnete ${ }^{\odot}$ Service provide the necessary technology that is available for all prisons to embark on tele-health projects with every guarantee of security and sustainability, since it does not generate any increase in public expenditure.

8. Tele-health projects should be documented and based on well-known clinical guidelines, such as those available at the American Telemedicine Association.

9. A framework program on TMD drawn up by the General Secretary of Prisons would be desirable. Its aim would be to further the development of this new and exciting way to relate to patients.

\section{CORRESPONDENCE}

Miguel Mateo Soler

Centro penitenciario El Dueso/CIS

"Jose Hierro"

C/Peña Sagra, 18. 39011 Santander.

E-mail: miguel.mateo@dgip.mir.es

\section{REFERENCES}

1. Oh H, Rizo C, Enkin M, Jadad A. What Is eHealth (3): A Systematic Review of Published. [Internet]. J Med Internet Res. 2005;7:e1. [fecha de acceso 13 Nov 2018]. Disponible en: https:// www.jmir.org/2005/1/e1/

2. Telemedicine Glossary. [Internet]. En: American Telemedicine Association. ATA; 2018. [fecha de acceso 27 Dic 2018]. Disponible en: http://thesource.americantelemed.org/resources/telemedicine-glossary

3. Pohl M. HIPAA, GDPR and connected health Interview with Jovan Stevovic, CEO of Chino.io. [Internet]. En: Research 2 Guidance; 2018. [fecha de acceso 23 Dic 2018]. Disponible en: https:// research2guidance.com/hipa-gdpr-and-connected-health-interview-with-jovan-stevovic-ceoof-chino-io/

4. Ornes S. Core Concept: The Internet of Things and the explosion of interconnectivity. [Internet]. Proc Natl Acad Sci USA. 2016;113:1105960. [fecha de acceso 20 Dic 2018]. Disponible en: https://www.ncbi.nlm.nih.gov/pmc/articles/ PMC5056067/

5. Mehta N, Pandit A. Concurrence of big data analytics and healthcare: A systematic review. [Internet]. Int J Med Inform. 2018;114:57-65. [fecha de acceso 15 Dic 2018]. Disponible en: https:// www.clinicalkey.es/\#!/content/journal/1-s2.0S1386505618302466

6. Coll J. Salud Conectada. Rev SEIS. [Internet]. 2016;115:6-13. [fecha de acceso 28 Dic 2018]. Disponible en: https://seis.es/wp-content/ uploads/2018/02/Revista-115.pdf

7. DICOM Digital Imaging and Communication in Medicine. [Internet]. National Electrical Manufacturers Association; 2018. [fecha de acceso 28 Dic 2018]. Disponible en: https://www.dicomstandard.org/

8. WHO (World Health Organization). Telemedicine: opportunities and developments in Member States: report on the second global survey on eHealth. Global Observatory for eHealth series [Internet]. WHO; 2010. Vol. 2. [fecha de acceso 10 Dic 2018]. Disponible en: https://www.who. int/goe/publications/goe_telemedicine_2010. $\mathrm{pdf}$

9. A Century of Telemedicine, Curatio Sine Distantia et Tempora. Vladzymyrskyy A, Jordanova M, Lievens F, eds. Sofia; 2016.

10. Sanborn CJ, Seibert DJ, Sanborn DE, Pyke HF, Ferland SF, Welsh GW. Speech therapy by inte- 
ractive television. [Internet]. Community Health (Bristol). 1974;6:134-7. [fecha de acceso 3 Abr 2019]. Disponible en: https://www.ncbi.nlm.nih. gov/pubmed/4459019

11. Prieto L, Sacristán JA, Pinto JL, Badia X, Antoñanzas F, Del Llano J. Analysis of costs and results of the economic assessment of health interventions. [Internet]. Med Clin (Barc): 2004;122:4239. [fecha de acceso 11 Dic 2018]. Disponible en: http://www.elsevier.es/es-revista-medicina-clinica-2-articulo-analisis-costes-resultados-evaluacion-economica-13059544? referer=buscador

12. Welch BM, Harvey J, Nathaniel S, O'Connell $\mathrm{N}, \mathrm{McElligott} J \mathrm{~J}$. Patient preferences for directto-consumer telemedicine services: a nationwide survey. [Internet]. BMC Health Serv Res. 2017;17:784. [fecha de acceso 10 Ene 2018]. Disponible en: https://www.ncbi.nlm.nih.gov/pmc/ articles/PMC5704580/

13. Aznar AL. La eSalud en el entorno de los Seguros de Salud. [Internet]. En: XVIII Máster en Dirección Aseguradora Profesional. Madrid. 29 Sep 2017. Universidad Pontificia de Salamanca; 2017. p. 18-24. [fecha de acceso 11 Dic 2018]. Disponible en: https://www.fundacionmapfre.org/documentacion/publico/i18n/catalogo_imagenes/ imagen_id.cmd? idImagen $=1109583$

14. Mateo Soler M, Cobo C, Blasco AJ, Llerena S, Crespo J, Lázaro P. Eficiencia de un programa de telemedicina en el manejo de la hepatitis $\mathrm{C}$ en población reclusa. [Internet]. Rev Esp Sanid Penit. 2018;20:69. [fecha de acceso 20 Dic 2018]. Disponible en: http://www.sanipe.es/datos/RESP_ supl_2-2018.pdf

15. Modelo encuesta de satisfacción para el paciente telemedicina-teleconsultas. [Internet]. Ministerio del Interior. SGIP. CP El Dueso. 2017. [fecha de acceso 13 Ene 2019]. Disponible en: https://documentcloud.adobe.com/link/track? uri=urn $\% 3 \mathrm{~A}$ aaid\%3Ascds\%3AUS\%3A80331ee1-ed3a-4f179979-9a4af4c84eb7

16. UC Davis Health. UCDHS Telemedicine Clinical Consultation. Patient Satisfaction Survey. [Internet]. 2015. [fecha de acceso 13 Dic 2018]. Disponible en: https://health.ucdavis.edu/cht/pdf/ Specialties/Patient\%20Satisfaction\%20Survey. pdf

17. Morgan DG, Kosteniuk J, Stewart N, O'Connell ME, Karunanyake C, Beever R. The telehealth satisfaction scale (TeSS): reliability, validity, and satisfaction with telehealth in a rural memory clinic population. [Internet]. Telemed J E Health. [Internet]. 2014;20:997-1003. [fecha de acceso 20
Dic 2018]. Disponible en: https://www.ncbi.nlm. nih.gov/pmc/articles/PMC4457516/

18. Program Development: How to Start. [Internet]. En: Utah Telehealth Network. UTN; 2015. [fecha de acceso 20 Dic 2018]. Disponible en: https:// utn.org/support/development/program.shtml

19. Secretaría General de Instituciones Penitenciarias. Informe General. Centro Penitenciario Málaga II. [Internet]. Ministerio del Interior; 2017. p. 159. [fecha de acceso 13 Dic 2018]. Disponible en: http://www.institucionpenitenciaria.es/web/ export/sites/default/datos/descargables/publicaciones/Informe_General_2017_acc.pdf

20. Defensor del Pueblo. Informe anual 2017 y debates en las Cortes Generales. Vol I. 1 Informe de gestión. [Internet]. Madrid: Defensor del Pueblo; 2018. p. 187. [fecha de acceso 13 Ene 2019]. Disponible en: https://www.defensordelpueblo.es/wpcontent/uploads/2018/03/Informe_anual_2017_ vol.I.1_Gestion.pdf

21. Andrews M. Telemedicine Opening Doors To Specialty Care For Inmates. [Internet]. En: KHN Kaiser Health News. Kaiser Family Foundation; 2018. [fecha de acceso 9 Ene 2019. Disponible en: https://khn.org/news/telemedicine-openingdoors-to-specialty-care-for-inmates/

22. Maruschak L, Chari KA, Simon AE, DeFrances CJ. National Survey of Prison Health Care: Selected Findings. [Internet]. Natl Health Stat Report. 2016;96:1-23. [fecha de acceso 3 Nov 2018]. Disponible en: https://www.ncbi.nlm.nih.gov/ pubmed/27482922

23. Agencia Española de Protección de Datos. Tratamiento de datos en servicios de salud penitenciaria. Informe 018/2006. [Internet]. AEPD; 2006. [fecha de acceso 13 Nov 2018]. Disponible en: https:// www.aepd.es/informes/historicos/2006-0018.pdf

24. Grupo PRECA. Informe prevalencia de trastornos mentales en centros penitenciarios españoles (ESTUDIO PRECA). [Internet]. Barcelona. [fecha de acceso 13 Dic 2018]. Disponible en: https://consaludmental.org/publicaciones/EstudioPRECA.pdf

25. Cuadrado A, Llerena S, Cobo C, Pallas J, Mateo M, Cabezas J, et al. Microenvironment Eradication of Hepatitis C: A Novel Treatment Paradigm. [Internet]. Am J Gastroenterol. 2018;113:1639-48. [fecha de acceso 7 Dic 2018]. Disponible en: https://journals.lww.com/ajg/Abstract/2018/11000/Microenvironment_Eradication_of_Hepatitis_C_A.19.aspx

26. American Telemedicine Association. Quick Guide for Store-Forward Teledermatology for Referring Providers [Internet]. ATA; 2012. [fecha de acceso 10 
Nov 2018]. Disponible en: https://medschool.ucsd. $\mathrm{edu} / \mathrm{som} / \mathrm{fmph} /$ divisions/family-medicine/Documents/quickguide.pdf

27. Servicio Cántabro de Salud. Mensajería de Atención Sanitaria (MAS), envío de fotografía a dermatología. [Internet]. SCS; 2018. [fecha de acceso 7 Nov 2018]. Disponible en: https://jira.scsalud.es:9443/ download/attachments/10388019/MAS\%20-\%20 Teledermatolog $\%$ C3\%ADa.pdf?version $=28$ modif icationDate $=1538380413000 \&$ api $=\mathrm{v} 2$

28. Anexo: 6.1 Modelo de consentimiento informado para telemedicina-teleconsultas. [Internet]. SGIP. CP El Dueso; 2017. [fecha de acceso 20 Ene 2019]. Disponible en: https://documentcloud.adobe. com/link/track? uri=urn \%3Aaaid\%3Ascds\%3A US\%3A189f6fa6-2b10-4887-834e-dcb8cd812d18

29. Mateo M. Procedimiento general para prestar servicios de teleconsultas entre centros propios y concertados de la Red Sanitaria Pública y el Centro Asistencial El Dueso. [Internet]. SGIP. CP El
Dueso; 2017. [fecha de acceso 13 Feb 2019. Disponible en: https://documentcloud.adobe.com/ link/track? uri=urn \%3 Aaaid \%3 Ascds $\% 3$ AUS $\%$ 3A92ae3816-dd67-497f-818e-dae4520bd7c5

30. American Telemedicine Association. Practice Guidelines for Video-based Online Mental Health Services. [Internet]. ATA; 2013. pp. 21. [fecha de acceso 13 Dic 2018. Disponible en: https://www. integration.samhsa.gov/operations-administration/practice-guidelines-for-video-based-onlinemental-health-services_ATA_5_29_13.pdf

31. American Psychiatric Association, American Telemedicine Association. Best Practices in Videoconferencing-Based Telemental Health (April 2018). [Internet]. ATA; 2018. [fecha de acceso 19 Dic 2019. Disponible en: https://www.psychiatry.org/File\%20Library/Psychiatrists/Practice/ Telepsychiatry/APA-ATA-Best-Practices-in-Videoconferencing-Based-Telemental-Health.pdf 